\title{
Viewpoint
}

\section{Zootic Climax}

A. A. Beetle has misinterpreted many of our findings and our use of the term zootic climax in his paper, "The zootic disclimax concept", (J. Range Manage. 27:30-32). He has also quoted us out of context and failed to distinguish working hypotheses, subject to testing and rejection, from established conclusion. This has occurred to such an extent that we can only refer interested readers of the Journal to the original papers, copies of which are available from the Biologists' Office, National Park Service, Box 168, Yellowstone National Park, Wyoming 82190 . It is true that we, and others, have challenged some "traditional" interpretations of conditions on ungulate ranges in northwestern Wyoming, and some of the supporting evidence for the recent interpretations will be found in our papers cited by Beetle and in the following papers:

Gruell, G. E. 1973. An ecological evaluation of Big Game Ridge. U. S. Dep. Agr., Forest Serv., Intermountain Region. 62 p.

Cole, G. F. 1969. Elk of Grand Teton and Southern Yellowstone National Parks. Yellowstonc National Park. 192 p., mimco.

Loope, L. L., and G. E. Gruell. 1973. The ecological role of fire in the Jackson Hole area, northwestern Wyoming. Quarternary Res., 3(3):425-443.

Houston, D. B. 1973. Wildfires in northern Yellowstone National Park. Ecology. 54:1111-1117.

Meagher, Mary. 1973. Bison of Yellowstone National Park: Past and present. Nat. Park Serv., Sci. Monogr. Series, No. 1, 162 p. U. S. Govt. Printing Office.

Additional reports on these subjects are in preparation.-Douglas B. Houston, research biologist, and Glen F. Cole, supervising biologist, National Park Service, U.S. Dep. of the Interior, Yellowstone National Park, Wyoming.

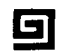

\section{CLYDE ROBIN}

\section{NATIVE SEEDS}

